University and University of Pennsylvania), clinical therapeutics, at the University of Pennsylvania; Dr. George E. Moore (University of Minnesota), surgery and onocology, at the University of Minnesota; Dr. C. Barber Mueller (University of Illinois and Washington University), surgery and biochemistry, at Washington University ; Dr. George W. Schwert, jun. (University of Minnesota), physical biochemistry, at Duke University; Dr. Beverly T. Towery (Vanderbilt), internal medicine and endocrinology, at Vanderbilt University; Dr. W. Clarke Wescoe (Cornell), pharmacology, at Cornell Univers. ity; Dr. Donald R. Wilson (Oxford and McGill), internal medicine and endocrinology, at the University of Alberta.

\section{Scholarships in the United States for British Students}

THe Coloraro School of Mines is offering a scholarship to a mole student from England for the academic year 1949-50. A separate offer is being made for Scotland. The scholarship is worth 425-475 dollars and 19 renewable for a maximum period of four years. Furcher particulars and application forms may be obtained from the Assistant Cultural Officer, U.S. Information Service, American Embassy, 5 Grosvenor Square, London, W.1, or from the secretary, Association of Universities of the British Commonwealth, 5 Gordon Square, London, W.C.1, with whom application forms must be lodged by May 1.

Harvard University announces that a fellowship, worth 2,000 dollars, provided by Mrs. Frank Knox in connexion with the Frank Knox Memorial Foundation, will be made available to enable a student from the British Isles to spend the academic year 1949-50 at Harvard. The fellowship is open to students of all stages; but preference will be given. to candidates who have graduated or are about to graduate in Great Britain or Ireland. There is no form of application. Further particulars can be obtained from the Secretary, Association of Universities of the British Commonwealth; applications must be completed by April 9 .

\section{International Conférence on Science Abstracting}

AN International Conference on Science Abstracting is to be held by Unesco in Paris during June 20-25. All Unesco and United Nations Member States will be entitlod to nominate three delegates. Representatiyes have also been invited from the specialized agencies of the United Nations and from the approprige international organisations such as the International Scientific Unions, the International Federation for Documentation and the International Organisation for Standardization. It is expected that the directors and editors of many of the most important abstracting services will be present at the Conference. Unesco will be glad to receive applications from persons other than officially appointed representatives who wish to attend as observers. The purpose of the Conference will be : "to consider and take action to improve and develop abstracting services for the natural sciences, both pure and applied, and to consider methods of increasing their usefulness to scientists, with regard at the same time to the related problems of indexing and accessibility of the recorded publications".

The Physical/Society: Seventy-fifth Anniversary Celebrations

THE celebration of the seventy-fifth anniversary of the Physical Society will take place on March 21. A conversazione will be held in the Royal Society's Rooms, Burlington House, Piccadilly, London, W.1, during 8-11 p.m., with the president, Prof. G. I. Finch, and Mrs. Finch as hosts. Admission is by ticket only. Earlier in the day, at 5 p.m., the Guthrie Lecture will be delivered by Prof. A. O. Rankine at the Royal Institution, 21 Albemarle Street, London, W.1, the subject being "Experimental Studies in Thermal Convection".

\section{Announcements}

MAJOR-Gganeral CYrIL Lloyd, director of Army Education, has been appointed administrative director of the Department of Technology of the City and Guilds of London Institute as from October 1, in succession to Lieut.-Colonel W. French.

A Davip Anderson Berry Silver-gilt Medal with a sum of $£ 100$ will be awarded in 1950 by the Royal Socigfy of Edinburgh for work on the therapeutical effect of X-rays on human diseases. Applications (with copies of accomplished work) must be sent to the General Secretary of the Royal Society of Edinburgh, 22 George Street, Edinburgh, 2, by March 31, 1950.

THE Arnold Gerstenberg Studentship for 1950 is open to students in the University of Cambridge who have obtained honours in the Natural Sciences Tripos and who went into residence not earlier than 1944 . The Studentship will be awarded for an essay which must be submitted before May 1, 1950; full details may be obtained from Mr. R. B. Braithwaite, King's College, Cambridge.

DR. K C. EDWARDs, reader in geography, has been appointed professor of geography, and Dr. E. J/W. Barrington, reader in zoology, has been appointed professor of zoology in the University of Nottingham. Both these chairs have just been established.

THE British Institute of Management will hold the fifty-thied in the 'Oxford' series of Management Conferences at Cliftonville during May 5-8. The form of the Conference has been altered, and the general purpose is to obtain a consensus of opinion among practising managers on certain fundamental and possibly controversial questions relating to the development of management, for the guidance of the Institute. Applications for tickets and all correspond. ence should be addressed to the Director, British Institute of Management, 17 Hill Street, London, W.l.

A воокLEx entitled "The Tilgate Story" has been issued by Messrs. F. W. Berk and Co., Ltd., of Commonwealth House, 1-19 New Oxford Street, Wh.1. This deals in a general way with the firm's research work on soil sterilization, deficiencies of soil nutrients, mercurial seed dressings, mercurized turf sand for the control of moss, and other mercury and copper fungicides and insecticides.

Mathematical Tables and Other Aids to Computation is a quarterly journal which is published and sub. sidized by the U.S. National Research Council. Not only io it running at a loss, but also costs are rapidly moynting. A substantial increase in the number of subscribers is necessary in order to avoid either increasing the price or reducing the size of the journal. The subscription-rate is 4 dollars per year, and full details may be obtained from the National Research Council, 2101 Constitution Avenue, Washington 25, D.C. In Great Britain the rate is 258 , and the agent is Scientific Computing Service, Ltd., 23 Bedford Square, London, W.C.I. 